\author{
Leszek Butowski \\ https://orcid.org/0000-0002-5885-7467 \\ University of Lodz \\ Faculty of Geographical Sciences \\ Institute of Urban Geography, Tourism and Geoinformation \\ leszek.butowski@geo.uni.lodz.pl
}

\title{
THE ORIGINS OF ACADEMIC WORK ON TOURISM: A EUROPEAN PERSPECTIVE ${ }^{1}$
}

\begin{abstract}
The purpose of this article is to fill in the gap in knowledge about early academic work on tourism which had developed first of all in Europe. The author has tried to achieve this aim by conducting a retrospective analysis of chronological and institutionalmethodological aspects of the evolution of tourism studies. As a result, he has distinguished two aspects (each divided into two): 1) chronological: a period of precursors and a formal academic period; 2) methodological: research within one discipline and interdisciplinary research. The results enabled the author to formulate general conclusions for critical discussion. It primarily concerns the domination of the English language and the Anglo-American tradition in the literature which is the reason why the global picture of achievements in tourism studies is incomplete and thus imperfect. The accomplishments of smaller, yet well-established, "national schools" are often ignored and remain almost unknown internationally. The author hopes that the article will be an encouragement to undertake research on early tourism studies in individual countries and to publish its results internationally as this will broaden knowledge of the origins of academic work in tourism.
\end{abstract}

Keywords: development of tourism studies, history and evolution, German school, French school, Italian school, Anglo-American domination, Polish achievements.

\section{INTRODUCTION}

The purpose of the article is to fill a gap in knowledge on early academic work on tourism and above all that which developed in Europe. The problem seems significant because contemporary authors, publishing their works mostly in English, commonly believe that tourism studies did not develop on a large scale until after World War II, and its heyday (still continuing) came only in the 1990s (Jafari, 1990, 2001). In addition, research in this domain is associated primarily with the achievements of the Anglo-American tradition, supplemented in recent decades with the findings of Australian and New Zealand researchers, as well as some from South-East Asia (remaining, however, under the influence of the English language tradition). This phenomenon, which is clearly visible in the predominance of English in contemporary research publications, has already been identified and critically described by both English-speaking academics and those coming from regions where other languages are spoken (e.g. Butowski, Kaczmarek, Kowalczyk-Anioł, Szafrańska, 2019; Chambers, Buzinde, 2015; Hall, 2004; Kozak, Kozak, 2016; McKercher, 2002; Wijesinghe, Mura, Bouchon, 2017).
However, the detailed results of the retrospective analysis presented here by the author clearly indicate that the beginnings of tourism studies should be sought in the countries of continental Europe outside the Englishspeaking area. These go back as far as the second half of the $19^{\text {th }}$ century, and have also been documented in works on the development of individual disciplines dealing with tourism

On the other hand, reconstructing the history of academic work on tourism, with consideration of the multiple disciplines related to it, seems to be very difficult if indeed possible. This can be seen by the fact that it has been relatively rarely attempted in a comprehensive way, and authors dealing with this issue, e.g. Vukonic (2012), Jafari and Xiao (2016) or Kozak and Kozak (2016), are few. Naturally, first we should ask about the purpose of such retrospective analysis. It is not just to mention authors and present their works, possibly relating to the achievements of individual disciplines, but it seems that research should lead to formulating some general conclusions. It should, to some extent, break the stereotypes regarding the contributions of individual 
academic schools and traditions (with respect to language as well) in the development of tourism studies. At the same time, conclusions from the analysis may form the basis for undertaking further research to provide a fuller picture of tourism phenomena in the contemporary world, embracing a maximally wide range of views. This could expand our knowledge about tourism and its various manifestations and allow us to understand it better.

Aware that completing this task goes beyond the framework of a single article, the author has attempted to at least partly reconstruct the origins of tourism studies.What is new here however is the methodological approach which places the author outside the singlediscipline system. Many works devoted to the history of tourism studies were written mainly from the point of view of a single discipline (e.g. Jackowski, Bilska-Wodecka, Sołjan, Liro, 2015; Jafari, Xiao, 2016) or at most of a group such as the social sciences (Dann, Liebman Parinello, 2009). Perhaps, an even more important move, due to which the author's results do not always confirm earlier findings (cf. Kozak, Kozak, 2016) especially with regard to early tourism studies, is his intentional stepping outside of the contemporary mainstream. They are typically presented in English and one of the negative effects is the fact that source investigations - so important for historical analysis - are limited to this particular language. Wishing to avoid this risk, an attempt was made to use sources other than in English, above all those published in French, German and Polish. At the same time, publications in English written by non-English speaking authors have been widely used, particularly when they concern the origins of tourism studies in their own countries. Naturally, the author is aware that the analysis presented here is incomplete, as it does not include reviews of research on tourism studies in a large number of countries. It seems, however, to be an objective drawback which should not prevent formulating conclusions from the study. On the other hand, it may be a challenge to continue research on the origins of tourism studies from the perspectives of other academic schools or language traditions that have not been mentioned.

\section{A RETROSPECTIVE ANALYSIS OF TOURISM STUDIES}

In view of the purpose of this study as well as considering its assumptions and limitations, the author has conducted a retrospective analysis of the development of tourism studies from two perspectives: chronological and institutional-methodological. As a result, he has distinguished mutually interconnected periods and research methods:
1. Two main research methods involving different methodological and institutional approaches:

- single-discipline studies (mono-faceted);

- interdisciplinary studies (multi-aspectual).

2. Two basic research periods (temporal aspect):

- the earlier, precursor research period (within a single discipline);

- the later, formal research period (within individual but also across multiple disciplines).

The distinction described above is presented in model form in Figure 1. A clear division into precursor and formal tourism periods turned out to be impossible because the two phases partly overlap. Thus, the model is illustrative only and the presented time lines are theoretical. This is the same with respect to the methodological-institutional division. Single-discipline or interdisciplinary research is often conducted at the same time or even by the same researchers at different periods. However, it seems that the distinguished periods and their methodological-institutional descriptions indicate general trends in the changes observed in the evolution of tourism studies in a long-term perspective. It is also worth noticing that the conception of tourism studies development presented here is partly an alternative, compared to Kozak and Kozak (2016) who distinguished three separate periods in tourism studies development: 1) before 1960; 2) 1960-1990;3) after 1990. It also differs from the periodization proposed by Vukonić (2012), who distinguished five stages in tourism theory development: 1) the period preceding tourism development (in its contemporary sense) - before the mid-19 $9^{\text {th }}$ century; 2 ) the second half of the $19^{\text {th }}$ century - when the first tourism studies were undertaken; 3) early $20^{\text {th }}$ century - before World War I; 4) the interwar period; 5) the period after World War II.

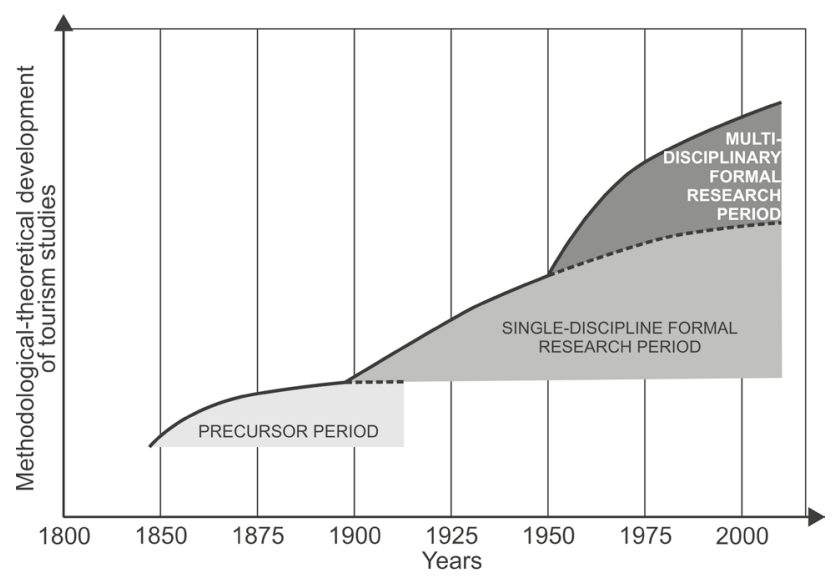

Figure 1. The methodological-theoretical development of tourism studies in real time Source: author

In view of the historical periods in the development of tourism studies presented above, the next part of the article presents a more detailed description, justifying the division proposed by the author. 
The precursor period, which started in the mid-19 $9^{\text {th }}$ century, includes works by those representing different disciplines who, apart from research typical of those disciplines, were also interested in tourism when it was not an autonomic object of study (research area). Obviously, the researchers were not using any specific concepts or terminology because they had only started to be created. The period of formal tourism studies was the time when they had "matured" enough to become an autonomic discipline, with their own (initially modest) conceptual apparatus and terminology, and even with some theoretical output and methods, usually borrowed from other, more advanced disciplines (mostly geography, economics and sociology) and adapted to the purposes of tourism studies. This has been described by many authors e.g. Bogucki and Woźniak (1997), Dann and Liebman Parinello (2009), Hau and Gartner (2012), Jackowski, Bilska-Wodecka, Sołjan i Liro (2015), Jafari and Xiao (2016) and Kowalczyk (2001).

Analysis of the origins of academic work on tourism from a methodological-institutional perspective has made it possible to distinguish two, in a way contradictory research approaches, involving single-discipline and interdisciplinary studies. The former is understood as research conducted from the perspective of one discipline (one aspect), without the need to make an interdisciplinary synthesis of the results. On the other hand, in interdisciplinary studies the distinguishing factor is the attempt to take a multi-faceted approach to a given problem, with the emphasis put on a synthetic interpretation of the results obtained within the framework of several disciplines. It is worth noting that while the first, precursor, stage of tourism studies was characterized by a single discipline approach (economics and geography were the main ones covering tourism studies), in the formal studies period (still continuing), both single discipline and interdisciplinary approaches are used. In the single discipline approach, some developed specific sub-disciplines focused on tourism issues ${ }^{2}$, such as tourism geography, tourism sociology, tourism anthropology, tourism economics, etc. (cf. Kozak, Kozak, 2016). It seems, however, that they often remain on the margin of mainstream research in their parent disciplines (cf. Dann, Liebman Parinello, 2009). The interdisciplinary approach, suggested by Tribe $(1997,2006)$ as the most promising, seems to be much more difficult, with respect to the methodology and organization of research, even though it is presently regarded as giving better results. This problem has been discussed by many authors, including Darbellay and Stock (2012), Leiper (1990), Smith (1998), Tribe and Liburd (2016). Kozak and Kozak (2016) believe that the development of the interdisciplinary approach was influenced by the fact that tourism issues started to be explored by the first generation of researchers who had gained their degrees specifically in this discipline, contrary to their predecessors who were originally educated as economists, geographers or sociologists. In the literature, depending how strongly the research results were synthesised, descriptions of various modifications and developments of the interdisciplinary approach can be found, which are referred to as multidisciplinary, cross-disciplinary, trans-disciplinary, or even postdisciplinary studies ${ }^{3}$ (Echtner, Jamal, 1997; Pearce, Butler, 1993; Rátz, 2014; Smith, 1998; Tribe, Xiao, 2011).

Considering the fact that the precursor period and the first phase of the formal tourism period (lasting, arbitrarily speaking, until World War II) have been less recognized, they will be the object of the historical analysis presented in this article ${ }^{4}$. The author's attention will be mostly focused on selected European countries due to the fact that it is in Europe (outside the English-speaking area) where examples of early academic work on tourism studies should be sought. This has also been confirmed by researchers from outside this continent and representing the 'Anglo-Saxon' tradition of tourism studies (Dann, Liebman Parinello, 2009; Vukonić, 2012; Jafari, Xiao, 2016). We may treat this statement as a hypothesis that needs to be verified, especially with regard to the works about tourism which were written by American authors (Brown, 1935; Carlson, 1938; Joerg, 1935; Jones, 1933; McMurry, 1930; Meinecke, 1929). It seems, however, that they had a dispersed character, probably due the researchers' diverse individual interests.

\section{THE PRECURSOR PERIOD}

The research conducted during the precursor period (especially its early phase) included a wide range of economic and geographical studies with their individual character depending on local economic, political and historical conditions. That is why, in individual countries or regions, different aspects were focused on. For example, in Poland (which had lost the status of a state at that time), the predominant type of research was geography focusing on ethnographic and cultural issues, often very patriotically-charged. On the other hand, German, Swiss, Austrian, French and Italian work was on the impact of tourism on a local economy, settlement system or environment, especially in the Alpine and coastal regions, as well as the historical cities visited by tourists. A little later, but still during the precursor period, strictly economics-oriented, practical work started to flourish, mainly for the purposes of local tourism economies. In Polish literature the early stage, mainly as a part of geographical as well as economic and social research, has been presented by Warszyńska and Jackowski (1978), Kowalczyk (2001), Jackowski and Sołjan (2011), as well as Jackowski, Sołjan, Bilska-Wodecka and Liro 
$(2015,2016)$ who analysed the accomplishments of the leading German and French schools. Geographers were the first ${ }^{5}$ to become interested in the phenomenon of tourism and trying to explain it and Jackowski, BilskaWodecka, Sołjan and Liro (2015) have formulated a thesis that research into tourism coincided with geography, turning towards issues of human existence in the natural environment. A theme which fitted into this trend perfectly was increasing human mobility, including tourism-related activity.

The most renowned German-speaking representatives of geography from the precursor period, whose achievements were the foundation of later formal tourism and economic research, include above all Alexander von Humboldt (1769-1859) (after: Jackowski, Bilska-Wodecka, Sołjan, Liro, 2015) - a naturalist, who observed the connection between the environment and human activity; Karl Ritter (1779-1859) - a regionalist, considered (next to Humboldt) to be one of the fathers of modern geography; Johann Georg Kohl (1808-1878) - a traveller, geographer and historian; Friedrich Ratzel (1844-1904) - considered to be one of the founders of anthropogeography; his student, Alfred Hettner (18591941) - an outstanding geographical theoretician; as well as Kurt Hassert (1868-1947) - and anthropogeographer, specializing in the geography of transport. Although none of these considered himself to be a tourism researcher, all of them, to a larger or smaller extent, dealt with tourism-related issues, either from an ethnographiccultural (e.g. Ratzel, 1882) or from a geography of settlement perspective (tourist destinations) (e.g. Hassert, 1908; Hettner, 1927; Kohl, 1841), only sometimes focusing on the economic aspect of tourist activity.

In the French-speaking area, the first name that should be mentioned is that of Paul Vidal de la Blache (1845-1918), whose humanistic and at the same time regional approach to geographical research established a very good methodological framework for tourism studies as well. According to Jackowski et al. (2015, 2020), it is Vidal de la Blache with another French geographer, Lasserre, who were responsible for introducing the term industrie touristique ${ }^{6}$ in reference to the development of the city of Lourdes, a famous pilgrimage destination (Lasserre 1930). In France, in the first decades of the $20^{\text {th }}$ century, the institutional basis of geographical research on tourism (however limited mainly to the mountainous areas of the Alps and the nearby Cote d'Azur, including Corsica) was the Institute of Alpine Geography (Institut de géographie alpine), established in Grenoble in 1907, as well as the "Revue de géographie alpine" - a journal published from 1913. Their founder was an outstanding geographer, Raoul Blanchard (1877-1965), whose interests included tourism and he devoted many publications to it, superseding, in a way, formal tourism studies (Blanchard, 1911, 1914,
1919). Before World War I, specialist guidebooks and journals appeared, intended for those specialising in some forms of tourism, e.g. Auscher's "Le tourisme en automobile" (1904), which published academic articles, too.

Obviously, the choice of works written by German and French researchers, illustrating the achievements of the precursor period in tourism studies, is not accidental. Generally, it has been agreed that it was in German- and French-speaking countries where this work had already started to develop in the $19^{\text {th }}$ century. It can be assumed, however, that it was also undertaken in several other countries (e.g. Poland), and above all in Italy (Avancini, 1925; Bodio, 1899; Stringer, 1912). Spode (2009) even claims that it was Italy (and not France) that was initially the most important centre of tourism studies, after German-speaking countries.

\section{THE FORMAL TOURISM STUDIES PERIOD}

Moving on to the formal tourism studies period, it should be emphasised that they naturally developed in Germanspeaking countries. The first publications on tourism, written mainly from an economic and geographical perspective ${ }^{7}$, on the hotel industry or tourism promotion, appeared there at the beginning of the $20^{\text {th }}$ century, and some even earlier. The authors writing from an economic perspective include Guyer-Freuler $(1874,1884$, 1895, 1905), Angerer (1881a, 1881b), Stradner (1890, 1905), Brougier $^{8}$ (1902), Just (1907), Müller (1908), SchullerSchrattenhofen ${ }^{9}$ (1911), Zollinger (1916), Glücksmann (1917, 1935), Sputz (1919), Morgenroth (1927), Bormann (1931), Krieger (1933) and Jaeger (1936). The authors of geographically-based works include Grünthal (1934) and $\operatorname{Poser}^{10}$ (1939).

It is worth noting that in as early as 1884, and ten years later in Graz, two important conferences were held devoted to promoting tourism. In 1914, in Düsseldorf, the Hotel Industry School (Internationales Institut für das Hotelbildungswesen) was founded, and transformed in 1920 into a vocational school (Hochschule für Hotel- und Verkehrswesen). Unfortunately, one year later, it was closed down due to the economic crisis (Geschichte der Tourismusforschung, 2020; Kozak, Kozak, 2016). A particularly noteworthy person at that time was Glücksmann (1929), who founded the Institute of Tourism Studies at the Berlin Higher Commercial School (Forschungsinstitut für den Fremdenverkehr der Handelshochschule Berlin) $)^{11}$ and started publishing probably the first academic journal dedicated to tourism studies in the world, entitled "Archiv für den Fremdenverkehr" (Haedrich, Kaspar, Klemm, Kreilkamp 1998; Spode 2009). In 1934, at the Vienna Economic 
University, the Institute of Tourism Studies (Institut für Fremdenverkehrsforschung der Wirtschaftsuniversität Wien) was established. Symbolically, the first stage of formal tourism studies in German can be added to the institutional ${ }^{12}$ and academic achievements of the "Swiss school" (Bernecker, Kaspar, Mazanec, 1984; Kozak, Kozak, 2016; Spode, 2009), and especially the works of Hunziker and Krapf $(1941,1942)$, whose theoretical work is still the basis for many terminological analyses in this field.

Summing up the heritage of tourism studies in the German-speaking countries before World War II, it should be emphasized that to many researchers it had become the main area of their academic interest (hence their work has been classified as belonging to the formal studies period). However, they mainly conducted their research with reference to single disciplines (mostly economics-based). An exception here is the activity of Institutes of Tourism Studies in Berlin (Spode, 2009) and in Vienna, which represented the interdisciplinary approach. The innovative proposal by Hunziker, formulated in the 1940s, who suggested recognizing tour ism as a separate discipline, should also be mentioned. Looking at the work of the German language school (developing in Switzerland, Germany and Austria) from a $21^{\text {st }}$ century perspective, it is quite clear that it was the predominant school until the $1960 \mathrm{~s}^{13}$. In that decade, it started to lose significance to the benefit of British and American academics, who became increasingly interested in tourism issues.

As regards tourism research in the first decades of the $20^{\text {th }}$ century by French academics, it seems that the transition from the precursor stage to formal tourism studies took place after the end of World War I ${ }^{14}$. With reference to that period, the urban planning and tourism study by Auscher and Rozet (1920), works by Blanchard (1919), including the geographical-tourist monograph on the Isère River and Grenoble region (1925), and the economic-tourist study by Gide (1928, after: Hsu, Gartner 2012), should be mentioned above all. The growing interest in tourism studies was also largely connected with the success of the International Exhibition of Hydropower and Tourism (Exposition internationale de la houille blanche et du tourisme) organized in Grenoble which drew the attention of public authorities and business circles to the importance of tourism for local and regional development (Jackowski, Bilska-Wodecka, Sołjan, Liro, 2015). As a result, in France, more and more publications started to appear (initially mainly on geographers' initiatives) where tourism issues were discussed (Borrel, 1933; Chaix, 1932; Miège, 1933). Except Grenoble, other centres where tourism studies were conducted were the universities in Toulouse, Bordeaux and Pau (Jackowski, BilskaWodecka, Sołjan, Liro, 2015).
The position on the predominant role of researchers from German-speaking (mostly economists) and French-speaking (mostly geographers) countries at the beginning of the formal tourism studies period is confirmed by the authors of a collective work entitled "The Sociology of Tourism. European Origins and Developments", edited by Dann and Liebman Parinello (2009), as well as work by Cohen (1984), Homberg (1978) and Spode (2009). Their analyses indicate that formal tourism studies, viewed from a broad sociological perspective (single-discipline approach - social sciences) started in the 1930s and were mainly undertaken in German (Glücksmann, 1935; Knebel, 1960; Wiese, 1930). From the 1950s, they were also developing in French-speaking countries, leaving a rich theoretical heritage in social studies ${ }^{15}$. It is also worth noting that during the initial period of sociological and anthropological research on a wide range of recreation issues (especially in France, the Netherlands, Belgium, and even the USA), leisure time and recreation occupied an important position (Dumazedier, 1962; Hourdin, 1962), with their specific conceptual apparatus and terminology (Fr. temps libre, loisir, Eng. free-time, leisure, superfluity). These referred to the $19^{\text {th }}$ century social theories of Marx, Engels and Weber, or to the principles of protestant ethics emphasising the dichotomy of work vs. free time (Dann, Liebman Parinello, 2009). Similar tendencies were observed after 1945 in the USSR and the communist bloc countries, but for purely ideological reasons. In view of the above, it should be noted that in some countries, formal tourism studies sensu stricto followed leisure time studies into the framework of social studies. It also seems that they did not start to dominate over sociological work on leisure time and recreation until the 1960s-1970s, when they become the main object of interest to social researchers (Lanfant, 1972). This position is shared in practice by Podemski (2005) who notices that the phenomenon of tourist travel was observed on a larger scale by sociologists at the turn of the 1950s and 1960s. It is noteworthy that the growing academic interest in tourism sensu stricto coincided with the dynamic development of such studies in 'Anglo-Saxon' countries (mainly in Great Britain and the USA, later also in Australia and New Zealand) and with the growing domination of English in the literature on the subject and academic life in general. It also seems that in those countries, since the 1970s, it has been possible to observe a gradual transition from a single discipline to an interdisciplinary approach to tourism studies, an important methodological breakthrough (cf. Dann, Liebman Parinello, 2009).

Going back to early tourism studies in other European countries before World War II, they were rather sporadic and carried out on a small scale. They did not start until the 1930s (with few exceptions) and were 
conducted in just a few countries, mainly Italy which has a long tradition, especially of the economic aspects (Savelli 2009). Italy can boast an abundant literature on the subject including (after: Hsu, Gartner, 2012) the works of Belotti (1919), Niceforo (1923), Benini (1926), Marriotti $^{16}$ (1923, 1931, 1933), Tabacchi (1934), Pedrotto (1939) and Troisi (1940a, 1940b). They are among major works from this period written in a language other than German and French.

Compared to the Italian output, the historical achievements of the British school (currently the leading one) look modest but mention first of all should be made of the macro-economic works by Ogilvy ${ }^{17}$ (1933) and Norval (1936). Britain is however where relatively early historical publications on travel around the European continent (Bates, 1911) had appeared, particularly those about the Grand Tour ${ }^{18}$ (Mead 1914), or a much later retrospective study on seaside spa resorts (Gilbert, 1939). This does not change the fact that British researchers only embarked on tourism studies on a large scale much later. Kozak and Kozak (2016) even claim that it did not take place until the early 1970s and was connected with the transition of the British economy from production to services. This opinion was also confirmed by Vukonić (2012) in his study devoted to the development of tourism theory.

Apart from the countries mentioned above, tourism studies in Europe (before 1939) were sporadically undertaken in Scandinavia, Belgium and the Netherlands (Ramarker, 1951), and probably in some other countries as well, though on an incomparably smaller scale. In fact, the publications listed in this paragraph should be included in formal tourism studies although they were written from the perspective of single disciplines, mainly geography, economics or sociology. Many researchers had already treated tourism as the main area of their interest, perhaps with the exception of those who conducted strictly historical research (Towner, Wall, 1991).

As for interest in tourism studies outside Europe, the United States of America should be mentioned first. Interestingly, the scale and significance of research before the end of the 1930s were much smaller than in the Old World. In the first decades of the $20^{\text {th }}$ century, publications presenting tourism issues appeared relatively rarely but included, for instance, economic (or geographical-economic) works by Brown (1935), Carlson (1938) and Jones (1933), or planning-geographical works by Joerg (1935), McMurry (1930), and Meinecke (1929). Most of them were purely practical, which fitted well into the pragmatic dimension of academic activity in the USA, shown by the fact that already in the 1920s, the University of Cornell (1922), and the College of Business at the Michigan State University (1927) had opened schools educating tourism workers (Kozak, Kozak,
2016). Kowalczyk (2001) indicates that in the 1930s, apart from North America, tourism studies were also found in $\operatorname{Japan}^{19}$, at least in a geographical respect.

\section{THE ORIGINS OF TOURISM STUDIES IN POLAND}

The main reason for including a separate section devoted to the academic and organizational achievements of Polish researchers as regards the first phase of tourism studies was the intention to present an 'off-stream' country, functioning in a given political, social and cultural situation which was able to develop a model of tourism studies. Its achievements in this respect have been quite well described (at least in the Polish literature), thus there is no need to quote them in detail at this point. However, it is worth noting the particular character of this model, especially at the precursor period. It is certain that it resulted from an exceptional political situation (lack of statehood until 1918) which had an influence on the direction of research and, as a consequence, on the interests and academic evolution of those working in the formal studies period. It should also be stressed that Polish scholars working at that time on tourism issues referred to works by German-speaking researchers (especially within the Prussian sector), as well as the achievements of the "French school". In view of this, it can be assumed that due to external conditions, the specific "Polish model" was not closed and it creatively supplemented other European work. However, the most important purpose is to postulate the need to study other "national models" of tourism studies and the publication of their results internationally ${ }^{20}$. This will make it possible to supplement our knowledge about the origins of academic work in individual countries whose achievements are a part of the global output.

Returning to the "Polish model", it seems that, compared to the accomplishments of the initial phase of tourism studies in the leading countries, the successes of Polish researchers from that period should be rated relatively highly, both as regards research and didactic activity. It should be stressed it acquired an institutionalized form as a 'Tourism School' (Studium Turyzmu), founded by Leszczycki and functioning from 1936 to 1939 at the Jagiellonian University in Kraków where it was one of the few institutions in Europe conducting research and didactic work. However, it was not created from scratch, as tourism studies had already had some tradition in Poland. It also seems that the political conditions and lack of statehood were the reasons why in the precursor period (lasting until 1914), research focused mainly on discovering the relationships between the homeland and its culture, traditions and religion. 
In this sense, they could be regarded as ethnographicchorographic studies, similar to contemporary cultural tourism studies and, on a larger scale, to the humanistregional concepts of Vidal de la Blache. From this period, a number of the most important names, such as S. Staszic (1755-1826) - sometimes called the father of Polish cultural tourism ${ }^{21}$, J.U. Niemcewicz (1758$1841)^{22}$ - a traveller and poet, W. Pol (1807-1872) - who used Humboldt's and Ritter's approach in his studies, O. Kolberg 23 (1814-1890) and Z. Gloger ${ }^{24}$ (1845-1910) - ethnographers and folklorists, T. Chałubiński (18201889) - a doctor and naturalist called the "discoverer" of Zakopane, should be mentioned. From a little later, the names of M. Zaruski (1867-1941) - a sailor, mountaineer and poet, a co-founder of the Tatra Voluntary Rescue Team; A. Janowski ${ }^{25}$ - the co-founder of the Polish Society for Cultural Tourism; Mieczysław Orłowicz (1881-1959) - an outstanding cultural tourism specialist and author of tourist guidebooks, or even M. Karłowicz (1876-1910) - a composer, mountaineer and publicist, should be recalled. At this point, several associations helped to discover the homeland by, for example, organizing journeys: the Filomath Society and the Filaret Association (1820-1823) ${ }^{26}$, the Tatra Society (founded in 1873), Warsaw Rowing Society (1878), Warsaw Cyclists' Society (1884), Polish Cultural Tourism Society (1906), the University Tourism Club (1906), the Carpathian Association of Skiers (1907), or less known and founded slightly later - the Podole Cultural Tourism Society (1925) and Wołyń Cultural Tourism Society (1927).

The people mentioned above represented various domains of social life, and only some of them were involved directly in academic work. However, their output was a good basis to begin regular tourism studies during the interwar period, booming in the second half of the 1930s when the Tourism School (Studium Turyzmu) was founded in 1936 and continued its activity until the outbreak of war. The history of the didactic and research activity of this institution has been well documented by many authors, mainly Jackowski (with his co-workers), Leszczycki (1992), Tokarski (1992) and Wyrzykowski (2014). A critical synthesis of their work is a large work, contributed to by several academics (Jackowski, Bilska-Wodecka, Sołjan, Liro, 2015) devoted to the 'Tourism School', presenting its history and achievements and comparing them to the accomplishments of other countries. Regrettably, the mainstream of those comparative discussions was limited to tourism geography, and the heritage of other disciplines was barely mentioned. In a sense, this article is an attempt at least partly to fill this gap. The observation made by the work's writers may seem a little surprising. They claim that "compared to the European countries and the United States, typical tourism geography started to develop in Poland relatively late, in fact after 1930"
(Jackowski, Bilska-Wodecka, Sołjan, Liro, 2015, p. 26). It can be agreed that this claim is justified with regard to the achievements of German and French geographers. On the other hand, Polish work seems quite successful, both in its academic-cognitive and didactic aspects, mainly due to the activity of the 'Tourism School'. The writers confirm this in another part of this publication (Jackowski, Bilska-Wodecka, Sołjan, Liro, 2015, p. 13):

The Tourism School - established in 1936 as a part of the Geographical Institute at the Jagiellonian University, was unique on an international scale. It played a significant role in the development of Polish and world tourism geography, as well as spatial and regional planning, connected with tourist activity and the preparation of future tourism sector workers in Poland.

\section{SUMMARY AND CONCLUSIONS}

To sum up the origins of tourism studies presented in this article, several general conclusions may be formulated, and also presented in the form of theses. They should undergo critical analysis or perhaps even become an inspiration for further research regarding the evolution of academic work on tourism, especially in areas not mentioned here.

1. In view of the achievements of various academic schools and traditions, it seems unquestionable that tourism studies started to develop on a larger scale at the turn of the $20^{\text {th }}$ century on the European continent, mainly in Germany, Austria and Switzerland, as well as in France and Italy. It was due to the dynamic tourism development in specific, though relatively small, geographical areas belonging to these countries (the Alps, coasts, historical cities), which had certain economic, spatial-environmental and social consequences. The changes first drew the attention of economists and geographers, followed by sociologists, making tourism a new object of research in these disciplines. Tourism studies in their first phase were of purely practical nature, which may explain the considerable "delay" in their undertaking by British and American researchers. Great Britain and the USA were countries which, above all, generated tourism, but to a much smaller extent, receiving it, along with all its economic, environmental or social consequences.

2. Apart from the real-life factors mentioned in conclusion 1 , the development of tourism studies initiated in the German-speaking area and in France was also triggered by the solid theoretical-methodological foundations in which the first work was undertaken. Special attention should be paid to the work of the $19^{\text {th }}$ century German school of anthropogeography 
(Anthropogeographie) and the French tradition of geographical regional studies, conducted from the humanist perspective (géographie humaine). An equally important role in the early days was played by the rich heritage of both countries as regards wideranging social thought and theory. Taking this into consideration, it can be assumed that the researchers undertaking the first studies on tourism, including those from outside France and German-speaking countries, naturally borrowed from their rich work.

3. Retrospective analysis of the development of tourism studies, conducted from the broadest perspective possible, going beyond one country, one language area or one academic tradition, has made it possible to distinguish three basic phases, partly overlapping in the temporal sense, showing distinctive methodologicalorganizational features:

- the precursor period - historically the earliest - when tourism researchers, not yet equipped with any specific methodological instruments, or any adequate theoretical foundations for a new area of study, were forced to rely on the work of other, more advanced disciplines. Tourism researchers were originally involved in those disciplines and fully identified themselves with them while studying tourism. Practically, it meant that tourism studies were conducted within research paradigms ruling individual disciplines;

- the formal tourism studies period - characterized by the single-discipline approach - is chronologically the second stage in the development of academic work on tourism, and also follows methodologicaltheoretical advancement. During this period, tourism acquired the status of a specific research area, explored from the point of view of various disciplines, using their theoretical work and methodological instruments adjusted to the character of the object of study. Simplifying, it can be assumed that the distinctive feature of this period and its peak phase is the evolution of several sub-disciplines, such as tourism geography, tourism economics, tourism sociology, etc. It is worth noting, however, that research in this phase, despite considerable methodological advancement, was still based on the paradigms ruling individual disciplines;

- the formal tourism studies period characterized by an interdisciplinary approach is one of the most advanced phases of tourism studies, with regard to theory and methodology. Its most distinctive feature is putting emphasis on the interdisciplinary synthesis of the results of research conducted from the perspective of individual disciplines. This synthesis is the most important added value and determines the theoretical development. It is, at the same time, a kind of breakthrough which involves researchers breaking away from the institutional and methodological roots of the disciplines they derive from. In view of this, granting tourism the status of a specific study area or regarding it as an independent discipline seems to be of secondary importance and this has been the subject of heated discussions in the last three decades (Butowski, 2011; Leiper, 2000; Tribe, 2000).

4. When comparing the origins of academic work on tourism in individual countries, it can be noticed that in some of them formal tourism studies developed using the achievements of the precursor period. This particularly concerns continental Europe (Germany, Austria, France, Italy, Poland). In the countries where the precursor period had not occurred to this extent (English language area, mainly Great Britain and the USA), tourism studies started to develop practically from scratch. This does not change the fact that researchers dealing with tourism in these countries borrowed heavily from theoretical work in other disciplines (economics, sociology, anthropology, geography, and later also management and marketing sciences).

5. As a result, formal tourism studies have included single-discipline studies (or a group of related disciplines) and interdisciplinary studies. It seems that the single-discipline approach is more common in countries which have gone through the precursor period, characterised by researchers' strong attachment to their parent disciplines (e.g. in Poland). In the areas where English is spoken (the language that has dominated the international academic debate over tourism), the interdisciplinary approach is much more common. It is particularly visible among researchers who gained their academic degrees on strictly tourism-related research.

6. Assuming that the conclusions formulated earlier are true, the well-known and often quoted model of tourism evolution, proposed by Jafari $(1989,2001)$, can be critically referred to, the so-called knowledgebased platform. He distinguished several subsequent phases (referred to as platforms), describing tourism development in individual periods. The knowledgebased platform which is a phase during whose main task was to understand tourism as a complex phenomenon in the contemporary world, with the help of the research instruments offered by modern disciplines, was one of these. It was positioned as the fourth, chronologically, and its development period was established as the $1990 \mathrm{~s}^{27}$. Considering the facts presented in this article, the last decade of the $20^{\text {th }}$ century, indicated by Jafari as the one in which the need for academic recognition was most important, seems too late. This was probably due to Jafari's excessively anglocentric view of global work on tourism, down- 
playing the heritage of continental Europe. This assumption seems to be confirmed by the fact that regardless of the period in which we place the dynamic development of tourism studies - the 1960s (Butler, 2015) or 1990s, (Jafari, 1989, 2001; Kozak, Kozak, 2016), to some extent it corresponds to the development of the interdisciplinary approach (more or less the 1970s and 1980s) which was primarily the domain of the Anglo-American school.

7. If we want to reconstruct the origins of tourism studies as fully as possible, it is necessary to consider achievements in the countries outside the main academic schools and traditions, or language zones, such as Germany, Austria, Switzerland, France, and later also Great Britain, the USA, Australia and New Zealand. These achievements were often a valuable supplement to mainstream work. Regrettably, they remain nearly completely unknown internationally. A good example is Poland, where regular and well institutionalized tourism studies had been conducted since the 1930s and researchers had been taking advantage of the achievements of the precursor period since at least mid-1 $19^{\text {th }}$ century. It can be assumed that similar situations might have taken place in other European countries too, often characterized by different historical, political, social, economic or environmental conditions which certainly had an influence on the development of tourism studies. Unfortunately, knowledge about tourism research usually remains 'closed' within these countries (and their language traditions) and is rarely presented outside, especially in the English-language mainstream literature. This situation certainly contributes to solidifying incomplete, thus somewhat mistaken opinions about the origins of tourism studies, especially among the younger generation of English-speaking researchers, but which at least some of them are aware (Butler, 2015; Dann, Liebman Parinello, 2009).

8. In view of conclusion 7 , it seems that research on the origins of tourism studies undertaken in various countries should be continued and the results should be presented internationally, in languages understood by a wider audience. This would fill in the existing cognitive gap and make it possible to better understand the development of academic work on tourism on a global scale, including the achievements of local schools and traditions. Even though this is exactly the aim of this article, its author is aware that the scope of the analysis is insufficient by far (if only because of linguistic limitations) and it should definitely be enlarged by the accomplishments of other countries, outside areas where English, French, German and Polish are spoken, the particular areas which were the main source of information necessary to write this article.
9. The author hopes that the challenges suggested above will be faced. It might even take the form of polemics (which is equally valuable), perhaps questioning to some extent the findings and theses presented in this work. They certainly carry the imprint of subjectivism (sometimes unintentional) whose aim was to draw the reader's attention to the incomplete thus distorted knowledge about the contribution of smaller countries and research centres on tourism studies.

\section{ENDNOTES}

${ }^{1}$ The article is a part of a monograph entitled Methodology of tourism studies: ontological and epistemological rudiments, and historical-institutional development, submitted by the author for printing at the Polish Economic Publishing House.

2 Their achievements at individual stages of research were often presented in special publications, e.g. Podstawy geografii turyzmu (Warszyńska, Jackowski, 1978), Fondements pour une géographie du tourisme et des loisirs (Cazes, 1992), The Sociology of tourism: Theoretical and empirical investigations (Apostolopoulos, Leivadi, Yiannakis, 1996), Geografia turyzmu (Kowalczyk, 2001), Socjologia podróży (Podemski, 2005), Geographie der Freizeit und des Tourismus (Becker, Hopfinger, Steinecke, 2007), The study of tourism: Anthropological and sociological beginnings (Nash, 2006), Ekonomika turystyki (Panasiuk, 2008), The study of tourism - foundations from psychology (Pearce, 2011), The discovery of tourism economics (Dwyer, 2011), Geography of tourism (Mason, 2017), Géographie du tourisme et des loisirs (Duhamel, 2018).

${ }^{3}$ It should be remembered, however, that including postdisciplinary studies into interdisciplinary research results in a logical mistake: interdisciplinarity assumes the existence of disciplines by definition, while post-disciplinarity means rejecting them (Szczepański, 2013).

${ }^{4}$ The methodological aspect of tourism studies development in 1945-2000, especially with reference to tourism activity, has been presented in the Polish literature by, e.g., Alejziak (2018).

${ }^{5}$ This statement seems valid, most of all as regards French and Polish researchers. In German-speaking countries, the predominant role was played by economists.

${ }^{6}$ The term was also adopted in English as tourism industry or hospitality industries. In Polish, it functions only as a loan translation (przemyst turystyczny), pushing out gospodarka turystyczna (tourism economics) which is closer to the original.

${ }^{7}$ Kozak and Kozak (2016) claim that at their early stage, formal tourism studies were dominated by economic research, due to the economic needs of the countries recovering after World War I.

${ }^{8}$ In 1902, Munich, he gave a lecture entitled The influence of tourism on the development of Bavaria (Spode, 2009).

${ }_{9}$ Treating tourism (Ger. Fremdenverkehr) very broadly - as a sum of all economic activities involving travel.

${ }^{10}$ Apart from the quoted authors, Vukonić (2012) mentions other names of German speaking researchers, who undertook tourism themes at that time, e.g. F. Bartsch, P. Mechter from Austria, as well as L. Woerl, F.M. Buschel, G. Ströhmefeld, O. Kamp, K. Köhne, M. Krauss, F. Oppenheimer, M. Klafkowski. K. Thiess, R. Bodo, K. Brenner, D. Tremohlen, E. Dietl, W. Mahleberg, E. Sutter, A. Rockstrob or F. Drosihn from Germany.

${ }^{11}$ The Institute existed until 1935 (according to other sources - 1934), when it was closed down due to the economic crisis. It 
was also significant that the founder, R. Glücksmann was of Jewish origin (Spode, 2009).

${ }^{12}$ In 1941, also in Bern, Forschungsinstitut für Fremdenverkehr (Institute of Tourism Studies) was founded.

${ }^{13}$ Many important theoretical tourism studies, authored by German-speaking researchers, were created in the 1950s. They include macro- and micro-economic works by Thoms (1952), Krapf (1953), Joschke (1953), Bernecker (1956), Walterspiel (1956a, 1956b, 1956c) or Hunziker (1959).

${ }^{14}$ However, many earlier works by Blanchard $(1911,1914)$ can be qualified as formal tourism studies.

${ }^{15}$ At the same time, it is worth noting that other authors who, in a sense, can be regarded as precursors of social studies regarding leisure time and tourism, include Veblen (1899) with his famous work The theory of the leisure class, Lévi-Strauss (1955) with his equally renowned piece, entitled The sadness of the tropics (Fr. Tristes tropiques), as well as Simml (1908) with the figure of "a stranger" created by him (Ger. der Fremde). Paradoxically, the authors of the first two texts were very critical about leisure time activities (Veblen) and travel (Lévi-Strauss). None of the three researchers treated tourism (recreation, travel) as the main object of academic interest; it was used rather to describe the society from specific research perspectives. The works created by these researchers were definitely an inspiration for others, who undertook the subject of tourism sensu stricto.

${ }^{16}$ In as early as 1925, at the University of Rome, he gave lectures dedicated to economic aspects of tourism (Medlik, 1965).

${ }^{17}$ They concerned, among other things, economic aspects of tourism as invisible export. According to Vukonic (2012), an inspiration for Ogilvie was the work by Mun (1664).

${ }^{18}$ One of the first works on Grand Tour was Dialogues on the use of foreign travel. Considered as a part of an English gentleman's education, between Lord Shaftesbury and Mr. Locke by Hurd (1764).

${ }^{19}$ The author does not quote specific sources.

${ }^{20}$ Regrettably, the majority of publications in English, the output of the non-mainstream countries is virtually disregarded (cf. Kozak, Kozak, 2016). This probably results from the insufficient knowledge of their authors, at least as regards the development of tourism studies in countries such as Poland, former Yugoslavia or former Czechoslovakia. An exception could be the collective work written by authors from many countries, under the editorship of Dann and Liebman Parrinello (2009).

${ }^{21}$ The author of $O$ ziemiorództwie Karpatów i innych gór i równin Polski (Staszic, 1815).

22 The author of Podróże historyczne po ziemiach polskich między rokiem 1811 a 1828 rokiem odbytych (Niemcewicz, 1858), published many years after his death.

${ }^{23}$ The author of a monumental work entitled Lud. Jego zwyczaje, sposób życia, mowa, podania, przysłowia, obrzędy, gusła, zabawy, pieśni, muzyka i tańce, published from 1858 (see: Kolberg, 1857-1890). Before the author's death, 33 volumes had been published, ten of which were included in the Ethnographic pictures series.

${ }^{24}$ The main author of Encyklopedia staropolska ilustrowana, published in four volumes, in 1900-1903 (see Gloger, 1900-1903)

${ }^{25}$ The author of Wycieczki po kraju - a four-volume work, published in 1900-1903 (Janowski, 1900-1903)

${ }^{26}$ The trend to travel and discover one's own or foreign countries was characteristic of the Romanticism period all over Europe. The journeys were even called les voyages touristiques, and the most famous travellers from that period, mentioned by Vukonić (2012) include J.W. Goethe, F.R. Chateaubriand, Ch. Nodier, Stendhal, G.G. Byron, G. Sand, H. Heine, A. Dumas or A. de Musset. Unfortunately, he forgot to mention F. Chopin or A. Mickiewicz.

${ }^{27}$ A different opinion is represented by Butler (2015), who referred to the 1960s as a period od a dynamic development of tourism studies, at least in Northern America.

\section{REFERENCES}

Alejziak, W. (2018). Research on tourist activity in Europe: Methodological aspects and results (Part I: The period 1945-2000). Folia Turistica, 46, 9-48. DOI: https://doi. org/10.5604/01.3001.0012.0842

Angerer, J. (1881a). Das Fremdenwessen im deutschen Südtirol. Bozen: Comm.-Verl. d. Promperger'schen Buchhldg.

Angerer, J. (1881b). Statistischer Bericht der Handels-und Gewerbekammer en Bozen. Bozen: Promperger in Comm.

Apostolopoulos, Y., Leivadi, S., Yiannakis, A. (1996). The sociology of tourism: Theoretical and empirical investigations. London: Taylor \& Francis Ltd.

Auscher, L. (1904). Le tourisme en automobile. Paris: Éditions Vve Ch. Dunod.

Auscher, L., Rozet, G. (1920). Urbanisme et tourisme. Paris: E. Leroux, Coll, Urbanisme.

Avancini, M. (1925). Statistica del movimento turistico in Italia. Anno 1924. Roma: Tipografia del Senato.

Bates, E.S. (1911). Touring in 1600: A study in the development of travel as a means of education. London: Constable.

Becker, C., Hopfinger, H., Steinecke, A. (2007). Geographie der Freizeit und des Tourismus. Bilanz und Ausblick. Munich: Oldenburg Wissenschaftsverlag $\mathrm{GmbH}$.

Belotti, B. (1919). Il diritto turistico nella legge, nella dottrine e nella giurispreudenza. Milano: Touring Club Italiano Milano.

Benini, R. (1926). Sulla riforma dei metodi di calcolo dei movimento turistico. Roma: [s.n.].

Bernecker, P. (1956). Die Stellung des Fremdenverkehrs im Leistungssystem der Wirtschaft. Vienna: Österreichischer Gewerbeverl.

Bernecker, P., Kaspar, C., Mazanec, J. (1984). Zur Entwicklung der Fremdenverkehrsforschung und - lehre der letzten Jahre. Vienna: Service-Fachverlag der WU Wien.

Blanchard, R. (1911). Grenoble. Études de géographie urbaine. Paris: A. Colin.

Blanchard, R. (1914). Le tourisme en Corse. Revue Mensuelle du Touring Club de France, 24, 2-7. DOI: https://doi.org/10.3406/ rga.1914.4810

Blanchard, R. (1919). Nice et les Alpes maritimes. Esquisse Économique. Les Alpes Économiques, 6, 109-119.

Blanchard, R. (1925). Le tourisme dans l'Isère, Grenoble et sa region. Grenoble: Allier.

Bodio, L. (1899). Sul movimento dei foresteri in Italia e sul dinero chi vi spendono. Giornalle degli Economisti, 15, 54-61.

Bogucki, J., Woźniak, A. (1997). Turystyka. In: Z. Krawczyk (ed.), Encyklopedia kultury polskiej XX w. Kultura fizyczna-sport (p. 20). Warsaw: Instytut Kultury.

Bormann, A. (1931). Die Lehre vom Fremdenverkehr. Berlin: Verkehrswissenschaftliche Lehrmittelgesellschaft bei der Deutschen Reichsbahn.

Borrel, A. (1933). Le tourisme en France. Paris: J. Téqui.

Brougier, A. (1902). Die Bedeutung des Fremdenverkehrs für Bayern. Munich: Druck von H. Gldenbourg. DOI: https://doi. org/10.1515/9783486731729

Brown, R.M. (1935). The business of recreation. Geographical Review, 25, 467-475. DOI: https://doi.org/10.2307/209315

Butler, R. (2015). The evolution of tourism and tourism research. Tourism Recreation Research, 40 (1), 16-27. DOI: https://doi.org/ 10.1080/02508281.2015.1007632

Butowski, L. (2011). Tourism - an academic discipline (discursive article). Turyzm/Tourism, 21 (1-2), 17-24. DOI: https://doi. org/10.2478/v10106-011-0002-8

Butowski, L., Kaczmarek, J., Kowalczyk-Anioł, J., Szafrańska, E. (2019). Social constructionism as a tool to maintain an 
advantage in tourism research. Tourism Geographies, DOI: https://doi.org/10.1080/14616688.2019.1654537

Carlson, A.S. (1938). Recreation industry of New Hampshire. Economic Geography, 14, 255-270. DOI: https://doi.org/10.2307/141343

Cazes, G. (1992). Fondements pour une géographie du tourisme et des loisirs. Rosny: Breal.

Chaix, E. (1932). Une industrie nouvelle. Le tourisme. Revue de Deux Mondes, 7 (1), 63-93.

Chambers, D., Buzinde, C. (2015). Tourism and decolonisation: Locating research and self. Annals of Tourism Research, 51, 1-16. DOI: https://doi.org/10.1016/j.annals.2014.12.002

Cohen, E. (1984). The sociology of tourism: Approaches, issues and findings. Annual Review of Sociology, 10, 373-392. DOI: https://doi.org/10.1146/annurev.so.10.080184.002105

Dann, G., Liebman Parrinello, G. (eds) (2009). The sociology of tourism. European origins and developments. Bingley UK: Emerald Group Publishing Limited.

Darbellay, F., Stock, M. (2012). Tourism as complex interdisciplinary research object. Annals of Tourism Research, 39 (1), 441-458. DOI: https://doi.org/10.1016/j.annals.2011.07.002

Duhamel, P. (2018). Géographie du tourisme et des loisirs. Dynamiques, acteurs, territoires. Paris: Armand Colin. DOI: https://doi. org/10.3917/arco.duham.2018.01

Dumazedier, J. (1962). Vers une civilisation du loisir? Paris: Seuil.

Dwyer, L. (ed.) (2011). The discovery of tourism economics, tourism social science series. Vol. 16. Bingley: Emerald.

Echtner, C.M., Jamal, T.B. (1997). The disciplinary dilemma of tourism studies. Annals of Tourism Research, 24, 868-883. DOI: https://doi.org/10.1016/S0160-7383(97)00060-1

Geschichte der Tourismusforschung (2020). Retrieved from: https:// de.wikipedia.org/wiki/Geschichte_der_Tourismusforschung (18.06.2020).

Gilbert, E.W. (1939). The growth of inland and seaside health resorts in England. Scottish Grographical Magazine, 55, 116-135. DOI: https://doi.org/10.1080/00369223908735100

Gloger, Z. (1900-1903). Encyklopedia staropolska ilustrowana. Vol. 1-4. Warsaw: P. Laskauer i W. Babicki.

Glücksmann, R. (1917). Privatwirtschaftslehre des Hotelgewerbes. Berlin: M. Paschke.

Glücksmann, R. (1929). Das Ziel des Forschungsinstituts für den Fremdenverkehr. Sonderdruck aus der Zeitschrift "ver kehr und Bäder". Vol. 23. Berlin: Bäder - Verkehrs - Verlag G.m.b.H.

Glücksmann, R. (1935). Allgemaine Fremdenverkehrskunde. Bern: Verlag Stämpfli und Cie.

Grünthal, A. (1934). Probleme der Fremdenverkehrsgeografie. Berlin: Dissertation Handels-Hochschule.

Guyer-Freuler, E. (1874). Hotelwesen der Gegenwart. Zurich: Von Orell Füssli \& Co.

Guyer-Freuler, E. (1884). Das Hotelwesen. Zürich: Drück von Orell Füssli.

Guyer-Freuler, E. (1895). Beiträge zur Statistik des Fremdenverkehrs in der Schweiz. Zurich: Orell Füssli.

Guyer-Freuler, E. (1905). Fremdenverkehr und Hotelwesen. Berne (Germany): Verlag Enzyklopädie.

Haedrich, G., Kaspar, C., Klemm, K., Kreilkamp, E. (1998). Tourismus-Management und Fremdenverkehrsplanung. Berlin-New York: Walter de Gruyter. DOI: https://doi. org/10.1515/9783110815993

Hall, C.M. (2004), Reflexivity and tourism research. W: J. Phillimore, L. Godson (eds), Qualitative research in tourism (pp. 137-155). London: Routledge.

Hassert, K. (1908). Die Städte geographisch betrachtet. Leipzig: B.G. Teubner. DOI: https://doi.org/10.2307/198514

Hettner, A. (1927). Die Geographie, ihre Geschichte, ihr Wesen und ihre Methoden. Wroclaw: Ferdinand Hirt.
Homberg, E. (1978). Reisen-zwischen Kritik und Analyse; zum Stand der Tourismusforschung. Z. Kult, 28 (3), 4-10.

Hourdin, G. (1962). Une civilisation des loisirs. Paris : Calmann-Lévy. Hsu, C.H.C., Gartner, W.C. (2012). The Routledge handbook of tourism research. London: Routledge. DOI: https://doi. org/10.4324/9780203123287

Hunziker, W. (1959). Betriebswirtschaftslehre des Fremdenverkehrs: Der Fremdenverkehrsbetrieb und seine Organisation. Bern: Gurtenverlag.

Hunziker, W., Krapf, K. (1941). Beiträge zur Fremdenverkehrslehre und Fremdenverkehrsgeschichte. Bern: Publikationen des schweizerischen Fremdenverkehrsverbandes.

Hunziker, W., Krapf, K. (1942). Grundriss der allgemeinen Fremdenverkehrslehre. Zurich: Polygraphischer Verlag.

Hurd, R. (1764). Dialogues on the use of foreign travel. Considered as a part of an English gentleman's education, between lord shaftesbury and mr. Locke. London (the Strand): A. Millar; Cambridge: W. Thurlbourn and J. Woodyer.

Jackowski, A. (1992). Studium Turyzmu Uniwersytetu Jagiellońskiego (1936-1939). Zarys działalności dydaktycznej i naukowej. Zeszyty Naukowe UJ. Prace Geograficzne, 89, 39-59.

Jackowski, A., Bilska-Wodecka, E., Sołjan, I., Liro, J. (2015). Studium Turyzmu Uniwersytetu Jagiellońskiego (1936-1939) i jego rola w rozwoju geografii turyzmu. Cracow: Instytut Geografii i Gospodarki Przestrzennej Uniwersytetu Jagiellońskiego w Krakowie.

Jackowski, A., Sołjan, I. (2011). Próba nowego spojrzenia na początki geografii turyzmu w Polsce (do roku 1939). In: B. Włodarczyk (ed.), Turystyka. Księga jubileuszowa w 70. rocznice urodzin Profesora Stanisława Liszewskiego (pp. 33-51). Łódź: Wydawnictwo Uniwersytetu Łódzkiego.

Jackowski, A., Sołjan, I., Bilska-Wodecka, E., Liro, J. (2016). Geographical tourism research and education at the Jagiellonian University School of Tourism in Poland (19361939). History of Geo- and Space Sciences, 7, 91-101. DOI: https:// doi.org/10.5194/hgss-7-91-2016

Jaeger, F. (1936). Werbung im Fremdenverkehr. Eine wissenschaftliche Untersuchung unter besonderer Berücksichtigung der Tiroler Verhältnisse. Innsbruck: Gemeinschaftsverl der Sozialwiss. Arbeitsgemeinschaft.

Jafari, J. (1989). Structure of tourism. In: S.F. Witt, L. Moutinho (eds), Tourism marketing and management handbook (pp. 437-442). London: Prentice Hall.

Jafari, J. (1990). Research and scholarship: The basis of toursm education. Journal of Tourism Studies, 1, 33-41.

Jafari, J. (2001). The scientification of tourism. In: V.L. Smith, M.A. Brent (eds), Hosts and guests revisited: Tourism issues in the $21^{\text {st }}$ century (pp. 28-41). New York: Cognizant Communication Corporation.

Jafari, J., Xiao, H. (eds) (2016). Encyclopedia of tourism. [s.1.]: Springer Reference. DOI: https://doi.org/10.1007/978-3-319-01384-8

Janowski, A. (1900-1903). Wycieczki po kraju. Warsaw: selfpublished.

Joerg, W.L.G. (1935). Geography and national land planning. Geographical Review, 25, 177-208. DOI: https://doi. org/10.2307/209596

Jones, S.B. (1933). Mining and tourist towns in the Canadian Rockies. Economic Geography, 9, 368-378. DOI: https://doi. org/10.2307/140491

Joschke, H. (1953). Beitrag zur theoretischen analyse des fremdenverkehrsangebote. Jahrbuch für Fremdenverkehr, 2 (1).

Just, R. (1907). Die Gemeinde Arose, ihr Wirtschaftsleben vor und seit dem Fremdenverkehr. Zurich: J. Leemann.

Knebel, H.J. (1960). Soziologische Strukturwandlungen im Modernen Tourismus. Stuttgart: Ferdinand Enke.

Kohl, J.G. (1841). Der Verkehr und die Ansiedelungen der Menschen in ihrer Abhängigkeit von der Gestaltung der Erdoberfläche. Dresden: Arnold. 
Kolberg, O. (1857-1890). Lud. Jego zwyczaje, sposób życia, mowa, podania, przysłowia, obrzędy, gusła, zabawy, pieśni, muzyka i tańce. Multiple editions.

Kowalczyk, A. (2001). Geografia turyzmu. Warsaw: Wydawnictwo Naukowe PWN.

Kozak, M., Kozak, N. (2016). Institutionalisation of tourism research and education: From the early 1900s to 2000s. Journal of Tourism History, 8 (3), 275-299. DOI: https://doi.org/10.1080 /1755182X.2017.1284274

Krapf, K. (1953). Die touristische Konsum: Ein Beitrag zur Lehre von der Konsumption.

Krieger, W. (1933). Werbtechnik im Fremdenverkehr. Wien: [s.n.].

Lanfant, M.-F. (1972). Les théories du loisir. Sociologie du loisir et idéologies. Paris: Presses Universitaires de France - PUF.

Lasserre, P. (1930). Lourdes. Étude géographique. Revue géographique des Pyrénées et du Sud-Ouest, 1, 5-40. DOI: https://doi. org/10.3406/rgpso.1930.3942

Leiper, N. (1990). Tourism systems: An interdiscyplinary study. Occasion Papers, 2. Palmerston: Massey University.

Leiper, N. (2000). An emerging discipline. Annals of Tourism Research, 27, 805-809. DOI: https://doi.org/10.1016/S0160-7383(99)00118-8

Leszczycki, S. (1992). Geneza i powstanie Studium Turyzmu na Uniwersytecie Jagiellońskim w Krakowie. Zeszyty Naukowe UJ. Prace Geograficzne, 89, 9-37.

Lévi-Strauss, C. (1955). Tristes tropiques. Paris: Plon.

Marriotti, A. (1923). L'industria del forestiero in Italia: Economica e politica del turismo. Bologna: Zanichelli.

Marriotti, A. (1931). L'importanza economica del turismo. Firenze: Edizioni AESTI.

Marriotti, A. (1933). Corso di economia turistica. Roma: Instituto Geografico de Agostini.

Mason, P. (2017). Geography of tourism. Oxford UK: Goodfellow Publishers Limited. DOI: https://doi.org/10.23912/9781911396437-3402

McKercher, B. (2002). The privileges and responsibilities of being a referee. Annals of Tourism Research, 29, 856-859. DOI: https:// doi.org/10.1016/S0160-7383(01)00091-3

McMurry, K.C. (1930). The use of land for recreation. Annals of the Association of American Geographers, 20, 7-20. DOI: https:// doi.org/10.1080/00045603009356913

Mead, W.E. (1914). The grand tour in the eighteenth century. New York: Houghton Mifflin.

Medlik, S.R. (1965). Higher education and research in tourism in Western Europe. London: University of Surrey.

Meinecke, E.P. (1929). The effect of excessive tourist travel on California redwood parks. Sacramento: California State Printing Office.

Miège, J. (1933). La vie touristique en Savoie. Revue de Géographie Alpine, 21 (4), 749-817. DOI: https://doi.org/10.3406/rga.1933.5380

Morgenroth, W. (1927). Fremdenverkehr. Handwörterbuch der Staatswissenschaften, 4.

Mun, T. (1664). England's treasure by forraign trade or the balance of forraign trade is the rule of our treasure. London: Printed by J.G. for Thomas Clark.

Nash, D. (ed.) (2006). The study of tourism: Anthropological and sociological beginnings. Bingley: Emerald.

Niceforo, A. (1923). Il movimento dei forestieri in Italia. Roma: Tipografia del Senato.

Niemcewicz, J.U. (1858). Podróże historyczne po ziemiach polskich między rokiem 1811 a 1828 rokiem odbyte. Paris: A. Franck; Petersburg: B.M. Wolff.

Norval, A.J. (1936). The tourist industry: A national and international survey. The Economic Journal, 46 (184), 732-734. DOI: https://doi.org/10.2307/2224701

Ogilvie, F.W. (1933). The tourist movement. An economic study. London: P.S. King \& Son.

Panasiuk, A. (2008). Ekonomika turystyki. Warsaw: Wydawnictwo Naukowe PWN
Pearce, P.L. (2011). The study of tourism: Foundations from psychology. Bingley: Emerald.

Pearce, P.L., Butler, R. (eds). (1993). Tourism research: Critiques and challenges. London: Routledge.

Podemski, K. (2005). Socjologia podróży. Poznań: Wydawnictwo Naukowe UAM.

Poser, H. (1939). Geographische Studien über den Fremdenverkehr im Riesengebirge: ein Beitrag zur geographischen Betrachtung des Fremdenverkehrs. Göttingen: Vandenhoeck \& Ruprecht.

Ramaker, J. (1951). La sociologie du tourisme. Zeitschrift für Fremdenverkehr, 6 (2), 73-76.

Rátz, T. (2014). Crossdisciplinarity or tourismology? The scientific identity of tourism in Hungary. In: L. Butowski (ed.), Searching for the scientific identity of tourism research (pp. 35-57). Warsaw: Warsaw School of Tourism and Hospitality Management.

Ratzel, F. (1882). Anthropogeographie Grunzüge oder der Anwendung der Erdkunde auf die Geschichte. Stuttgart: J. Engelhorn.

Savelli, A. (2009). Tourism in Italian sociological thaught and study. In: G. Dann, G. Liebman Parrinello (eds), The sociology of tourism. European origins and developments (pp. 131-168). Bingley UK: Emerald Group Publishing Limited.

Schullern-Schrattenhofen, H. von. (1911). Frendemverkehr und Volkswirtscahft. Jahrbücher für Nationalökonomie und Statistik Zeitschriftenheft, 4, 433-491. DOI: https://doi.org/10.1515/ jbnst-1911-0130

Simmel, G. (1908). Soziologie. Untersuchungen über die Formen der Vergesellschaftung. Berlin: Duncker \& Humblot.

Smith, M. (1998). Social science in question. Towards a post-disciplinary framework. London: Sage.

Spode, H. (2009). Tourism research and theory in German-speaking countries. In: G. Dann, G. Liebman Parrinello (eds), The sociology of tourism. European origins and developments (pp. 65-94). Bingley UK: Emerald Group Publishing Limited.

Sputz, K. (1919). Die geographischen Bedingungen und Wirkungen des Fremdenverkehrs in Tirol. Doctoral thesis. Vienna: Uniwersytet w Wiedniu.

Staszic, S. (1815). O ziemiorództwie Karpatów i innych gór i równin Polski. Warsaw: Drukarnia Rządowa.

Stradner, J. (1890). Die Förderung des Fremdenverkehrs. Kulturbildern aus Steiermark, 257-288.

Stradner, J. (1905). Der Fremdenverkehr: Eine folkswirtschaftliche Studie. Graz: Leykam.

Stringer, B. (1912). Sulla bilanza dei pagamenti fra Italia e l'estero. Roma: Tipografia nazionale di G. Bertero e C.

Szczepański, J. (2013). Dyscyplina nauk o polityce. Status teoretyczny i prawny. Retrieved from: https://www.academia.edu/25428238/Dyscyplina_nauk_o_polityce_Status_ teoretyczny_i_prawny (20.08.2020).

Tabacchi, G. (1934). Turismo ed economia. Aspetti economici del fenomeno turistico. Roma: ENIT.

Thoms, W. (1952). Die Arten und der Charakter des Fremdenverkehrsbetriebs. In: Handbuch für Fremdenverkehrsbetriebs. Giessen: Hb Thoms.

Tokarski, Z. (1992). Wydawnictwa Studium Turyzmu Uniwersytetu Jagiellońskiego w Krakowie. Zeszyty Naukowe UJ. Prace Geograficzne, 89, 61-87.

Towner, J., Wall, G. (1991). History and tourism. Annals of Tourism Research, 18,71-84.DOI: https://doi.org/10.1016/0160-7383(91)90040-I

Tribe, J. (1997). The indiscipline of tourism. Annals of Tourism Research, 24, 638-654. DOI: https://doi.org/10.1016/S0160-7383(97)00020-0

Tribe, J. (2000). Indisciplined and unsubstantiated. Annals of Tourism Research, 27 (3), 809-813. DOI: https://doi.org/10.1016/ S0160-7383(99)00122-X

Tribe, J. (2006). The truth about tourism. Annals of Tourism Research, 33 (2), 360-381. DOI: https://doi.org/10.1016/j. annals.2005.11.001 
Tribe, J., Liburd, J.J. (2016). The tourism knowledge system. Annals of Tourism Research, 57, 44-61. DOI: https://doi.org/10.1016/j. annals.2015.11.011

Tribe, J., Xiao, H. (2011). Development in tourism social science. Annals of Tourism Research, 38 (1), 7-26. DOI: https://doi. org/10.1016/j.annals.2010.11.012

Troisi, M. (1940). Prima line di una teoria della rendita turistica. Padova: CEDAM.

Veblen, T. (1899). The theory of the leisure class. New York: Mac Millan.

Vidal de la Blache, P. (1922). Principes de géographie humaine. Paris: A. Colin.

Vukonić, B. (2012). An outline of the history of tourism theory. Source material (for future research). In: C.H.C. Hsu, W.C. Gartner (eds), The Routledge handbook of tourism research (pp. 3-27). London: Routledge.

Walterspiel, G. (1956a). Grundlagen der Betriebswirtschafts lehre des Fremdenverkehrs. Jahrbuch für Fremdenverkehr. Teil I JfF 4. Jg.: 3-13.

Walterspiel, G. (1956b). Grundlagen der Betriebswirtschafts lehre des Fremdenverkehrs. Jahrbuch für Fremdenverkehr. Teil II JfF 5. Jg.: 3-17.
Walterspiel, G. (1956c). Grundlagen der Betriebswirtschafts lehre des Fremdenverkehrs. Jahrbuch für Fremdenverkehr. Teil III JfF 5. Jg.: 39-46.

Warszyńska, J., Jackowski, A. (1978). Podstawy geografii turyzmu. Warsaw: Państwowe Wydawnictwo Naukowe.

Wiese, J. von. (1930). Fremdenverkehr als zwischenmenschliche Beziehungen. Archiv für den Fremdenverkehr, 1, 1-3.

Wijesinghe, S.N., Mura, P., Bouchon, F. (2017). Tourism knowledge and neocolonialism - a systematic critical review of the literature. Current Issues in Tourism, 22, 1263-1279. DOI: https:// doi.org/10.1080/13683500.2017.1402871

Wyrzykowski, J. (2014). Achievements of geographical sciences in Poland in tourism research. In: L. Butowski (ed.), Searching for the scientific identity of tourism research (pp. 127-144). Warsaw: Warsaw School of Tourism and Hospitality Management.

Zollinger, W. (1916). Fremdenverkehr und Zalungsbilanz. Jena: [s.1.]

Article received: 6 March 2020

Accpeted:

5 November 2020 